\title{
ANALYSIS OF EROSION CONTROL CONSTRUCTIONS EFFECTIVENESS. THE CASE OF A ROAD GULLY IN WIELKOPOLE (LUBLIN UPLAND)
}

\author{
Andrzej Mazur ${ }^{1}$, Radomir Obroślak' ${ }^{1}$, Kamil Nieścioruk', \\ Żanna Król', Justyna Gabryszuk', Roman Rybicki ${ }^{1}$ \\ Department of Environmental Engineering and Geodesy, University of Life Sciences in Lublin, Leszczyńskiego \\ Str. 7, 20-069 Lublin, Poland, e-mail: amazur70@op.pl, radomir.obroslak@up.lublin.pl,kamil.niescioruk@ \\ up.lublin.pl, zannakrol.up@o2.pl, justynagabryszuk@gmail.com, roman.rybicki@up.lublin.pl
}

Received: 2016.06 .30

Accepted: 2016.08.09

Published: 2016.09.30

\begin{abstract}
The paper contains analysis of the anti-erosion system in the road gully in Wielkopole, Lublin Upland. The solution implemented in the gully's bottom is effective against line erosion - there is no gully deepening. Lack of protection of slopes results in an intense earthmass movements. At the brim zone of the gully suffosion processes occur leading to the gully widening. The eroded material is accumulated on the road and colmatage drainage system of voivodship road no. 842 , what is dangerous to traffic and generates expenses. That is why anti-erosion systems should be implemented comprehensively, protecting both the slopes and the bottom of gullies. Projects of such systems should be consulted with specialist.
\end{abstract}

Keywords: water erosion, road gully, anti-erosion construction in gully

\section{INTRODUCTION}

The most destructive form of water erosion is a gully erosion. Gullies lower the quality of agricultural production space significantly and are the cause of loses on many fields of economy. They lead to destruction and drying of nearby fields, increase flood risk and water-transported sediment colmatage road infrastructure as well as watercourses and waterbodies [Józefaciuk, Józefaciuk 1998, Józefaciuk i in. 2001, Kociuba i in. 2014, Mazur 2011].

The Lublin Upland is heavily segmented with gullies, with about $50 \%$ of them being road gullies [Józefaciuk, Józefaciuk 1995]. Factors that are conductive to formation of such gullies are: diversified land forms, easily-eroded soils on loess rock and the domination of small farms characterised by irregular patchy pattern of tiny arable fields leading to a need of forming a number of field roads providing access to fields. Road gullies are a serious environmental and economic problem, which needs a deep analysis of erosion processes and their results, as well as well-devel- oped actions preventing formation of new gullies and stabilising these existing.

The work contains an analysis of anti-erosion constructions in a loess road gully in Wielkopole near Krasnystaw on the Lublin Upland.

\section{MATERIALS AND METHODS}

The analysed road gully (with erosion control constructions engineered in 2009-2010) is located in Wielkopole on the Lublin Upland, in the eastern part of mesoregion of the Giełczew Elevation (Wyniosłość Giełczewska in Polish), some $8 \mathrm{~km}$ west of Krasnystaw. The Giełczew Elevation is the highest, central part of the Lublin Upland with the peak in the village of Boży Dar (306 m a.s.1.) [Kondracki 2002]. Its core is formed by landforms of "hills", made of hard, non-karsting gaize and lime silicate rocks. Parallel plateaus landscape is interspersed with Sarmatian cap-covered inselbergs and dozen-meter thick loess patches with dry valleys and gullies. The dominant type of soil are these on loess rock [Geografia Polski 1999]. 
The research was done in 2015. It was based on field works mainly, when - after a surface run-off periods - qualitative and quantitative analyses of morphogenetic processes shaping the gully were conducted. The technical quality and effectiveness of anti-erosion construction were examined during field words. The gully morphometric characteristics were calculated using levelling of the gully's bottom with three cross sections. Elevations were measured with Nedo E28 dumpy level using temporary benchmarks on both ends of the gully. The absolute heights of benchmarks were measured using geometric levelling tied to the $3^{\text {rd }}$ class vertical control network. The topography of the catchment area was analysed with 1:10,000 map, measurement results and field reconnaissance.

\section{RESULTS}

The analysed gully (fig. 1) developed on loess-based soils on a south-east slope, where a rural road led to fields [Mazur 2008]. Its area reaches 1.8 ha, it is 900 meters long and 6 to 14 meters width. The gully is from 0.8 to 7 meters deep, with the left slope being 1 to 2 meters higher than the right one. Both slopes are steep, with a gradient of 1:0.5 in a lower part, 1:1.5 in an upper and vertical in most of a middle part. The width of a gully bottom is from 5 in a lower part to 7 meters in a middle part with an average of 5.5 meters. The maximum gradient of the bottom is $9.1 \%$ with an average equal to $5.3 \%$. In the lower part, on a section of about $3 \mathrm{hm}$, the gully direction is coincident with a slope direction, while in an upper part it is oblique. It resulted in a 3.5 ha catchment area in an upper part of the gully. The water from a catchment runs-off on a left slope of the gully into a middle and a lower part of it. The run-offs caused by a spring thaw or storm rainfalls activated erosion processes in the gully, resulting in high loss [Mazur 2008]. These were reasons for the commune of Gorzków authorities to protect the gully. Works were done during 2009-2010 and a concrete covering of a field road at the bottom of the gully was laid. Its thickness is about $20 \mathrm{~cm}$, width $-4 \mathrm{~m}$ and length reaches 800 meters. The bottom part of a right slope was additionally secured with a concrete openwork plates while on the left slope there was a channel constructed, made of concrete prefabricated trapezium-shaped elements and designed for directing the run-off water out of the gully.

The 100 meters long part of a road below the gully mouth has been hardened with concrete plates. The lower 180 meters long section of a gully has have its right slope gradient lowered.

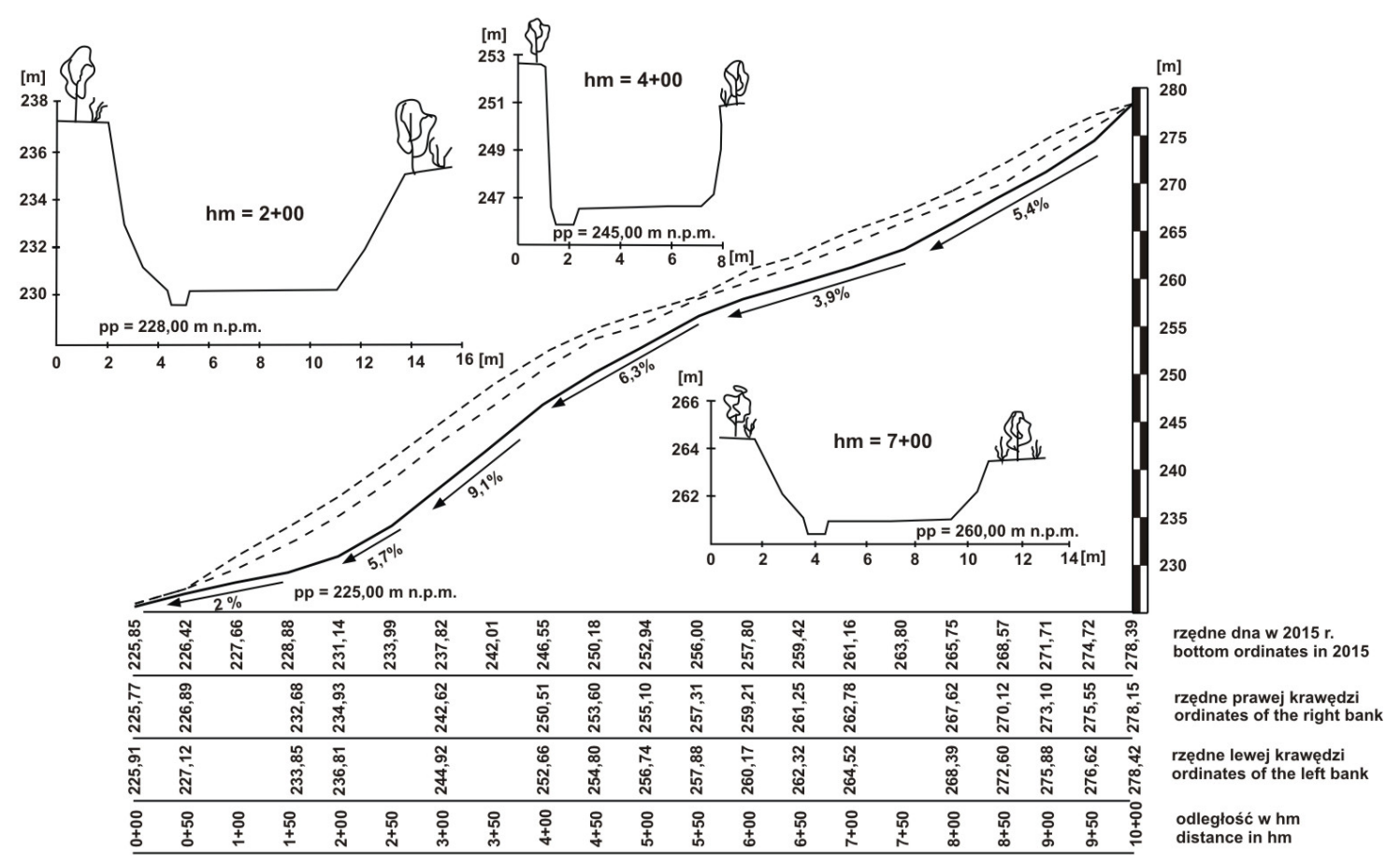

Figure 1. A longitudinal profile and cross-sections of the road gully 
During the research period, water surface run-offs were observed in April and May 2015. They resulted in numerous erosion-caused damages. What is important, the dominant form of the water erosion was no longer road damaging rill erosion, as it was before [Mazur 2008], but earthmass movement on slopes and suffosion. The concrete-hardening of a road was successful in protection against rill erosion and deepening of the gully as well as it increased the quality of a road transport while accessing arable fields. However, the concrete itself is highly corroded by water transporting small pieces of concrete off the road leaving concrete rills ( 2 to $4 \mathrm{~cm}$ width and as deep as $2 \mathrm{~cm}$ ) on its surface.

The suffosion processes occur on a left slope in a middle and a lower part of the gully. Four sinkholes have been identified in 2015 with diameter from 3 to 6 metres and depth of $3.5-5.5$ metres. They developed as a result of the inflow from 3.5 ha catchment on arable fields near the gully. With no safe catchment draining, water erodes or infiltrates slopes, resulting in development of sinkholes and suffosion corridors with outlets near the gully mouth. One of the corridors

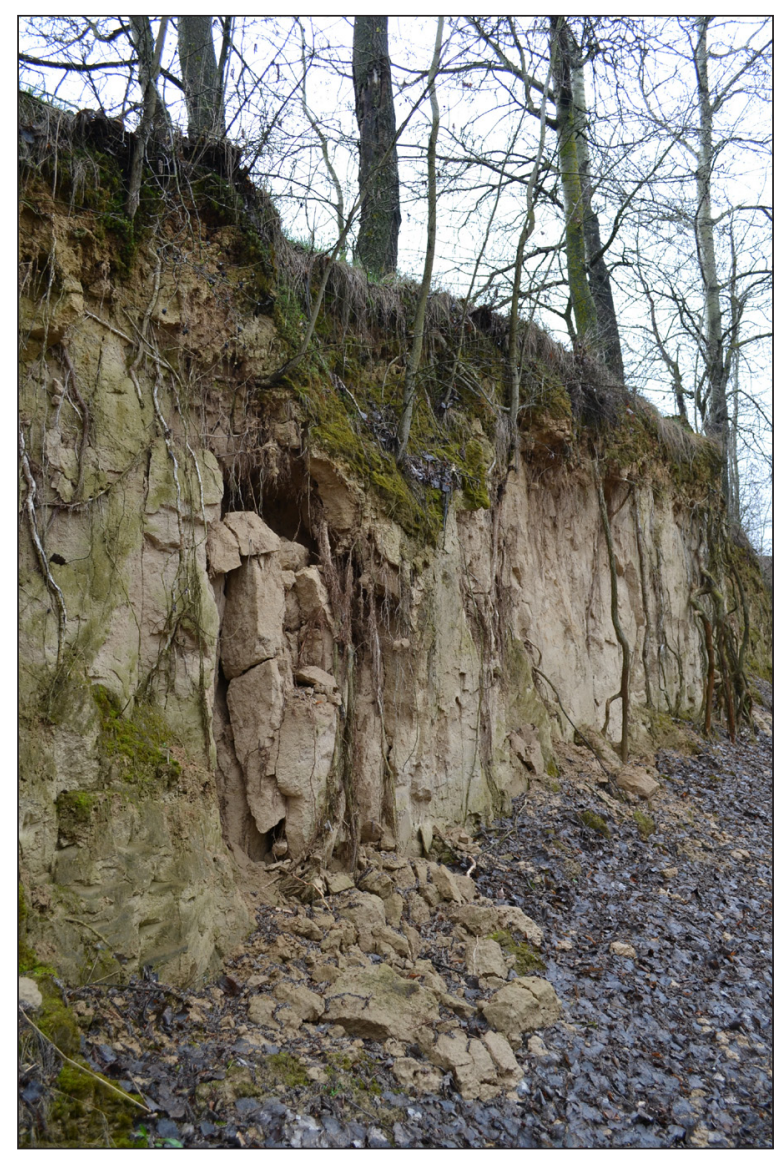

Figure 2. Loess falling off vertical slopes of the gully ceiling collapsed, forming a tributary gully 3.5 metres wide, 4 metres deep and 16 metres long. Field examinations reveal it is still very active in terms of erosion and develops constantly.

Earthmass movements were particularly active on steep slopes of the gully. Solifluction were also noted there, especially on parts with no plants. The influence of this factor on relief forming is small because of a limited occurrence of the phenomenon. A falling off is often seen form of erosion on vertical, non-covered with vegetation slopes in a lower and a middle part of the gully (Fig. 2). The total area of occurrence of this process was about 900 square metres of slopes. As the result, sediment cones of total volume of about 22 cubic metres developed at the foot of the slope. The creep processes were shaping the gully in its upper part too, what was accompanied by movements of earthmass with shrubs and herbaceous plants. They formed numerous shallow slump up to 0.4 metres deep and of total area of 12 square metres.

Accumulation of the eroded material took place at the bottom of the gully and below its mouth, on concrete plates. The material of approximately 11 cubic metres in total was accumulated in a form of sediment layers 4 to 16 square metres and of 1 to $6 \mathrm{~cm}$ in thickness. Part of the eroded material was accumulated in channel for run-off water, filling it to top in some segments. Most of the eroded material was, however, deposited in by-road ditches near voivodship road no. 842 (Krasnystaw Żółkiewka), filling them and, partially, on the road itself, leading to endangering the traffic. The total volume of about 60 cubic metres was accumulated on the road and in by-road ditches. The drainage system of the road no. 842 has been restored in 2010, when anti-erosion constructions have been built in the gully. The accumulated material was removed and ditches were shaped in a form of trapezoid (in section). Ditches need restoration again, as they have been colmataged and are defunct now.

\section{CONCLUSIONS}

Concrete hardening of the road in the gully turned out to be an efficient technical solution for line erosion problem. The process of the gully deepening stopped, quantity of eroded material decreased and a road accessibility of 
fields increased. The concrete surface is easily destroyed however and needs temporal restorations to prevent its damage. The run-off channel also fulfil its task in leading surface water off the gully to its mouth. It is sometimes colmataged, but earthmass accumulated this way is washed off in case of intense run-off. Despite the good anti-erosion constructions, limiting the extent of line erosion, the whole gully is not satisfactory protected against water erosion, as field works reveal. The surface water run-off activates erosion processes. Under-surface erosion was observed in brink areas of the gully. It is associated with water infiltration ad rinsing in loess, leading to creation of suffosion sinkholes and corridors. They, in turn, cause an increase of a spatial extent of the gully and destruction of arable fields. Falling off and detachment were most frequent and relief-forming earthmass movement processes observed on steep and vegetation-free slopes of the gully. They are typical gravitational processes triggered by periodical moistening of loess leading to separating loess blocks of the slope according to the rock texture. The extent of detachment and falling off were also increased by trees growing by the brink of the gully and penetrating a ground with their roots, leading to fragmentation of loess rock. The earth material eroded off the gully's slopes is deposited on its bottom and then transported with water (in channel) and accumulated on the road no. 842 and in by-road ditches causing danger in traffic. The road and ditches still need cleaning off the eroded material after intensive run-offs from the gully what generates constant expenses.

To prevent development of the gully and protect the road no. 842 and its draining system against colmatation, left slope of the gully has to have water inflow cut off or the water has to be directed to the gully's bottom with a hardened channel. A solution of this kind should eliminate under-surface erosion seen at the foot of the left slope. Trees by the brink of the gully should be removed as well, as they increase loess fragmentation with their weight and their roots penetrating the rock. As a next step, steep and vertical slopes should be transformed to have a gradient of 1:1 and should be technically and biologically protected to eliminate earthmass movements.

\section{CONCLUSIONS}

1. Erosion processes cause the development of the analysed gully, being a threat to nearby arable fields.

2. The most active water erosion forms were, during the research period, suffosion and earthmass movement, both on steep, uncovered by vegetation slopes of the gully.

3 . The eroded material washed off the gully colmatage the road no. 842 and its draining system, causing danger in traffic.

4. The anti-erosion constructions have to be done in a comprehensive way, protecting not only the bottom, but also the slopes of the gully. Projects of gully anti-erosion melioration system should be consulted with specialist.

5. The inflow of water into a gully should be cut off to stabilize the situation. Other solution could be directing the water to the gully's bottom, reducing slopes gradient and protect them biologically and technologically

\section{REFERENCES}

1. Geografia Polski. Środowisko przyrodnicze. 1999. Praca zbiorowa pod red. L. Sterkela. Wydawnictwo Naukowe PWN, Warszawa.

2. Józefaciuk A., Józefaciuk Cz. 1995. Erozja agroekosystemów. PIOŚ Biblioteka Monitoringu Srodowiska, IUNG Puławy.

3. Józefaciuk Cz. Józefaciuk A. 1998. Erozja gleb i melioracje przeciwerozyjne $\mathrm{w}$ regionie wyżyn południowowschodniej Polski. Cz. III. Zagospodarowanie wąwozów. Bibl. Fragm. Agron., t. 4 A, 197-227.

4. Józefaciuk Cz., Nowocień E., Wawer R. 2001. Rozwój wąwozu drogowego i koncepcja jego zabudowy. Folia Universitatis Agriculturae Stetinensis 217, Agricultura 87, 69-72.

5. Kociuba W., Janicki G., Rodzik J. 2014. 3D laser scanning as a new tool of assessment of erosion rates in forested loess gullies (case study: Kolonia Celejów, Lublin Upland). Annales UMCS, Sectio B: Geographia, Geologia, Mineral. et Petrogr., vol. 69, 107-116.

6. Kondracki J. 2002. Geografia regionalna Polski. Wydawnictwo Naukowe PWN, Warszawa.

7. Mazur A. 2008. Rozwój wąwozu drogowego w Wielkopolu (Wyżyna Lubelska). Przegląd Naukowy Inżynieria i Kształtow. Środowiska, 17, 2(40), 70-77.

8. Mazur A. 2011. Rozwój wąwozu dolinowego w Wielkopolu (Wyżyna Lubelska) w latach 2003 2009). Zesz. Probl. Post. Nauk Roln., 560, 177-182. 